\title{
An analysis of the changing dynamics of Sino-Russian relations in Central Asia
}

\author{
Asma Rashid*1 ${ }^{1}$ Taqdees Tahir ${ }^{2}$ \\ 1. Department of Politics \& International Relations, International Islamic University, Islamabad, Pakistan. \\ 2. Department of Social and Political Sciences, Universita degli Studi di Milano, Milano, Italy. \\ *Corresponding Author Email: asma.rashid@iiu.edu.pk | asmawaqar87@gmail.com
}

\begin{abstract}
This paper analyses China's growing presence in Central Asia and its consequences on Sino-Russian bilateral relations. Global leading economic powers are establishing relations with Central Asian states and are actively investing in the trade and energy sector. China is becoming an influential external actor due to its energy and security interests linked to this region as it will decrease Chinese dependence on Middle East for its energy needs. Russia has been considering Central Asia as important domain of its great power and never allowed any other state to replace its hegemony in Central Asia. Though China and Russia have witnessed a bitter past but now cooperating for their mutual interests in Central Asia. This paper aims to provide a historical perspective of Sino-Russian relations and an analysis of current engagement of China and Russia in Central Asia through the lens of neorealism. The methodology used in the research paper is secondary resources as the information has been gathered from books, articles, newspapers, websites, blogs, etc. The paper suggests that despite the Sino-Russian collision of interests in Central Asia, both major powers will continue to maintain peaceful coexistence to ensure economic development, peace, and prosperity in this region of the world.
\end{abstract}

Article History

Received:

September 19, 2021

Revised:

November 21, 2021

Re-revised:

December 24, 2021

Accepted:

December 26, 2021

Published:

December 31, 2021

Keywords: Central Asia, Sino-Russian relations, security, regional security, geostrategic position, great powers, great power competition, hegemony.

How to Cite: Rashid, A. \& Tahir, T. (2021). An analysis of the changing dynamics of Sino-Russian relations in Central Asia. Liberal Arts and Social Sciences International Journal (LASSIJ), 5(2), 272288. https://doi.org/10.47264/idea.lassij/5.2.19

Publisher's Note: IDEA PUBLISHERS (IDEA Publications Group) stands neutral with regard to the jurisdictional claims in the published maps and the institutional affiliations.

Copyright: ( 2021 The Author(s), published by IDEA PUBLISHERS (IDEA Publications Group).

Licensing: This is an Open Access article published under the Creative Commons AttributionNonCommercial 4.0 International License (http://creativecommons.org/licenses/by-nc/4.0/) 


\section{Introduction}

Since the end of the cold war, relations between China and Russia have been improved dramatically by developing close economic and trade ties, regional security and defence cooperation, and resolving border disputes through bilateral discussions. In the last three decades, both states have been aligned in a closer strategic partnership and often advocate similar positions in the international arena. Importantly, one of the reasons for the current trajectory of close and warm ties between China and Russia is the US dominance in the world where both nations have the same goal that is to tackle US hegemony and change the US-led international Power order.

However, there are potential constraints to the strengthened Sino-Russian relations that is the competition for dominance and control of Central Asia. China's growing political and economic influence in Central Asia represents a great threat to Sino-Russian partnership because the Russian Federation considers itself as a world power whose hegemony over the former five Soviet republics goes without saying. Moreover, the strategic and central location of Central Asia between China, Russia, and the Caspian states make this region a pivotal crossroad where the interests of both major powers are likely to collide, thus leading towards possible hostility.

China's growing influence in Russia's immediate backyard is raising asymmetry between both states. After the collapse of the Soviet Union, China has gradually but significantly increased its presence in Central Asia and filled up the vacuum left by Russia. Chinese active involvement in influencing the regional order of central Asia is backed by several key facts. Firstly, the absence of Western engagement in this region. Secondly, China's strong economic and secure footing in this region, e.g., Recently most of the central Asian economies are getting dependent on Beijing. Moreover, Central Asia states are a crucial source of natural resources needed by Chinese industries and also this region is allowing China to diversify its Energy sources (Melnikovová, 2020).

Despite China's growing political and economic ambitions in Central Asia, Russia's hegemony has not completely encroached on this region. Russia is still regarded as an important player in Central Asia mainly due to the common soviet's legacy embedded strongly between the former republics and Russian Federation. In many parts of Central Asia, the Russian language is widely used as lingua franca and Russian cultural influence is very prominent in all five states. Importantly, in terms of geopolitics, the region of Central Asia is a buffer zone against many challenges specifically coming from Afghanistan and Middle East e.g., terrorism, human and drug trafficking, the flow of extremist ideas, etc.

Against this background, this research paper examines the potential rivalry between China and Russia in Central Asia due to the emergence of China as the most influential external actor in Russia's immediate backyard, posing a great threat to Russia's leading position in this region. It answers the questions as: a) in the contemporary International System, does Russia have the power to maintain its dominant position in Central Asia? b) how does the power transition in Central Asia is leading China and Russia towards open rivalry? and c) what are the causes of the asymmetrical position of China and Russia in SCO and why Central Asian states are essential to China and Russia? 


\subsection{Sino-Russia relations in a historical perspective}

Historically, China and Russia have had been locked in complex and turbulent relations specifically from the seventeenth century until the Bolshevik revolution of 1917. This period is marked by oppression and competition between the two states with Russia being in a more dominant position. Both the states used to perceive one another as a threat to their national security and territorial integration in the second half of the Seventeenth century, Russia made several attempts to annex Chinese administered areas of Siberia but were forcibly beaten back by the Chinese Manchu ruler. However, in the mid-nineteenth century, the former USSR started extending its border till the Armor and Ussuri Rivers and the already weakened Chinese Qing Dynasty ceded more than one million square kilometre area of its land (known as Outer Manchuria) to Russia through "Unequal Treaties". The opium wars and the weakening of Qing Dynasty in China marked a change in their bilateral turbulent relationship (Mustafić \& Preljević, 2017).

However, after the establishment of the Republic of China in 1912 and the Soviet Union in 1917, Russia started influencing young China's political developments and followed by financial and military support against Japan in WW II with the aim that Chinese would provide a big help in the spread of Communism and also avoid the risk of China's fall to Japan. Furthermore, When the People's Republic of China came into being, the Sino-Russian relations were improved largely, and this phase is often called the "Honeymoon Phase" in Sino-Russian relations (Eder, 2014). The new leader of China Mao Zedong formally adopted a "leaning-toone-side" policy, supporting the socialist bloc and opposing capitalist camp (Lewis \& Xue, 1993). Along with that Russia also formed a formal alliance with China to provide military and economic support to Mao's embryonic regime, making Soviets "Big Brother" to the Chinese (Chase et al., 2017).

Although China and Russia were on good terms during the beginning of the cold war, however, their relations between both states again got strained and bitter in the 1960s and continued till 1980s. The antagonism was mainly due to two reasons. Firstly, the ideological differences as Mao didn't want Russia to control the International Communism movement (importantly after Stalin's death) and he wanted to pursue more radical policies economic and ideological policies and did not want to copy soviet style of economic, political, and ideological development. Secondly, border clashes grew between the two states mainly in DamanskyZhenbao Island and Ussuri River Further deteriorated the Relations between Russia and China and the breakup take the lead to the military confrontation to such extent that Russia was considering using nuclear weapons against is ex-friend China.

This animosity took a turn in the late 1980s with the demise of the Soviet Union when Russia became weaker, and China became dominant and opened up new avenues of cooperation between Russia and China. Both states started normalizing their relations and increasing economic cooperation. One of the major reasons for the improved relation was that both the states were ambitious to replace the Uni-polar world order with multipolarity in the international system. To resolve border issues, both states signed a demarcation agreement of the eastern part in the year 1991 followed by a demarcation pact on the western border in the year 1994 (Koldunova, 2008).

The strategic relationship was further strengthened when the "Shanghai Five Group" including 
Russia, China, Kazakhstan, Kyrgyzstan, and Tajikistan were formed in April 1996 to resolve the border disputes and for maintaining tranquillity (Bowen \& Yang, 2016). Later, it was transformed into "Shanghai Cooperation Organization (SCO) with the inclusion of Uzbekistan" (Bailes et al., 2007; Aslam \& Tariq, 2021). This organisation was aimed to reduce the transnational threats and aimed at increased economic and infrastructure cooperation along with a deeper goal of managing potential competition between Russia and China (Bailes et al., 2007). In 1999 Russia became the largest weapon supplier to China (Eder, 2014).

From 2000 onwards, both the states have had been established improved trade and economic environment, increasing their mutual influence in the world. In the year 2001, China and Russia signed the "Treaty of Good Neighbourliness, Friendship and Cooperation" (Peace Agreement Data Base, 2001) and this was considered as the first official agreement between the two states since the 1950s Sino-Soviet Treaty. This treaty will turn 20 in next year February 2022, and it is hoped that it will be extended automatically for next five years (Russian News Agency, 2021). In March 2013 President Putin visited China where both states signed an agreement for Strategic Comprehensive Partnership.

Currently, China and Russia have been celebrating their "Comprehensive Strategic Partnership" specifically since 2014 where both states have agreed to connect China's Silk Road Economic Belt with the Russian-led Eurasian Economic Union. Importantly, both states have signed 30 years $\$ 400$-billion Gas supply deal where Russia will supply gas to China. Putin acknowledged that "This is the biggest contract in the history of the gas sector of the former USSR" (Anishchuk, 2014). Not only this, but Russia is also China's largest oil supply. The movement of technology and weapons between both states is a two-way street. For example, Russia wants to purchase a Chinese-made warship and Russia is assisting China to make its nuclear early warning system. Similarly, in the context of bilateral trade, both states are agreed to avoid the use of the US dollar. It is important to mention that the reason for the close strategic alignment between Russia and China to date is to oppose and counter the US increased global hegemony (Goldstein, 2020) The two countries are engaged in a marriage of convenience though continue to diverge on matters related to their national interest.

\subsection{Central Asia's significance for China and Russia}

Central Asia represents a geostrategic and geopolitical land that has had a huge impact on the security and overall political order of the world. Having a population of about 72 million, the region lies at the crossroad of Asia, Europe, and the Middle East. The region is comprised of five former Soviets Republics that became independent states three decades ago which includes Kazakhstan, Kyrgyzstan, Tajikistan, Turkmenistan and Uzbekistan. After independence, the geostrategic environment of the region attracted the attention of international powers which resulted in the development of diplomatic relations between the outer world and regional actors of Central Asia.

The strategic landlocked location of Central Asia places it at the heart of Eurasia, neighbouring two major world powers, China to the east and Russia to the north and west and have close geographical proximity with two potential regional powers, India to the Southeast and Iran to the South (McFarlane, 2016). According to Halford Mackinder's geopolitical theory, the geography of Central Asia represents the most important place of the world, becoming the pivot point of geopolitics (Ismailova \& Papava, 2010). Mackinder stated this region as "Heartland" 
which ultimately leads to the dominance of the entire globe. "Who rules the Heartland commands the World-Island, who rules the World-Island commands the world" (Fettweis, 2000). Hence, the geopolitical central location and availability of rich energy resources make this region the "Heartland" of the modern international system.

In terms of physical geography, each Central Asian state has different individual dynamics based on ambiance, natural resources availability, suitable agricultural conditions, etc. The Central Asia region is hosting the second-largest energy reserves and also contains significant metals zinc, magnesium, silver, gold, uranium etc. Only Kazakhstan is abundant in mineral deposits that make it a world leader in reserves of coal, chromite, lead, and zinc, and its uranium deposits are estimated to be the second-largest in the world' (Placeholder3). It is also known to possess a great oil reserve. Kazakhstan's Kashagan oil field (in the Caspian Sea zone), which was discovered in 2000 has had been considered the largest oil discovery in the world in the past 20 years. This oil field was the second-largest oil field in the world at the time it was discovered (Eurasia Asia Review News \& Analysis, 2017).

The region of Turkmenistan contains a substantial location of giant natural gas reserves. According to the Oil and Gas Journal, Turkmenistan has the proven natural gas reserves of about 265 trillion cubic feet (Tcf) in the year 2016 and has 'become sixth largest natural gas holder in the world and was among the top 15 dry natural gas producer countries in 2015' (Eurasia Asia Review News \& Analysis, 2017). In the Eurasian region, Uzbekistan has been ranked as the third-largest natural gas producer after Russia and Turkmenistan. In 2015, the state companies produced about 2 Tcf of the natural gas. Importantly, the Caspian Sea is considered as the part of Central Asia as the eastern part of the sea comes in contact with the Central Asian region (Eurasia Asia Review News \& Analysis, 2017). The Caspian Sea possesses huge energy reserves and mineral wealth, thus increasing the strategic significance of the Central Asian states especially Kazakhstan and Turkmenistan. To extract the benefit from energy and mineral resources of the region, external actors are developing geo-strategy in connection to the geo economy.

\section{Literature review}

In a book "China-Russia Relations in Central Asia" author has described that China's connections with other major nations, particularly Russia, are continually renegotiated as it advances to global power status. Energy has an important role in both countries' foreign policies. An examination of Chinese language literature spanning the period 1997 to 2012 reveals a clash of interests over Central Asian reserves. While past forecasts of an approaching confrontation are dubious, descriptions of Sino-Essential Asian energy relations as "central to energy security" and categorical rejection of a Russian "sphere of influence" also rule out retreat (Eder, 2013). China will most certainly supplant Russia as the main player in Central Asia in the long run.

In a book author claimed that for years Sino-Russian relations the communist states have been seen as a quagmire. During first thirty years 1949-1979 of bilateral engagement, they have turned their relations from allies' adversaries. Their internal political set up is entirely different, however they managed to evolve strategic partnership. This book primarily answers that how do they both managed to overcome their differences for a common cause which is sometimes 
seen to be against US. The book then assesses the strengths and weaknesses of this partnership (Bellacqua, 2010).

In a report, the author asserted that the Sino-Russian strategic cooperation already has significant geopolitical clout, and if effectively implemented, it has the potential to shift the global power balance. China's rapid rise in comparison to Russia, is decreasing but has undeniably weakened the former superpower, is providing adjustment issues for both Beijing and Moscow. In fact, history demonstrates that large power transitions have always been difficult - politically, economically, culturally, and in terms of security. Despite the fact that Moscow and Beijing claim that their partnership has never been stronger and that it is obviously the most important strategic relationship for both countries, the obstacles of adapting to new circumstances remain.

In an article author said that in Eurasia and the Asia-Pacific region, the US-Russian-Chinese triangle is a delicate game that US must consider when devising a policy. While the ChineseRussian strategic cooperation is founded on discontent with a US-led international order and pragmatic concerns, it is not based on a common long-term constructive vision of the world order. As evidenced by conflicts over energy, weapons sales, and Russia's invasion of Crimea, this may limit and even erode it in the long run. This article looks at the Chinese-Russian strategic collaboration, focusing on the relationship's drivers as well as its stumbling blocks. It then looks at the Sino-Russian relationship (Bolt, 2014).

In an article the author says that the condition of Russia's relations with the West, particularly with the United States, has a significant impact on Russia's official approach toward China. The majority of shared Sino-Russian concerns concentrate around NATO and the US. Because of their education and beliefs, President Putin and his team were widely seen as Westernizers when they arrived at office. The majority of Putin's top officials are young, speak at least one European language, and have studied or worked in Europe or the United States. Putin's Westernism may stem from a belief rather than a desire to transform Russia into a Westernstyle democracy. The optimum path for Russian development is a rapid westward expansion (Lukin, 1999). In an article authors claim that Despite their divergent interests, Moscow and Beijing are continuously renegotiating their regional stances to avert potential clashes. Central Asian states are not bystanders in this situation (Asiryan, 2020).

Few studies of recent trends in Sino-Russian relations have provided a coherent examination of the factors underpinning increased bilateral collaboration. In the case of these elements, there has been a tendency to emphasise shared geopolitical interests, notably the desire to balance against the US (for example, in Lo's, Wilson's, and Wishnick's interpretations). To date, only a few publications have attempted to study current Sino-Russian cooperation in the context of International Relations theory, beyond brief theoretical excursions. This study makes an analysis of Sino-Russia relations through the lens of Neorealism.

\section{Theoretical framework}

This study uses a theory of Neorealism to explain the complexion of Sino-Russian relations in Central Asia. Neorealism holds that International System is anarchic which inevitably leads to the logic of self-help and power politics. The anarchical structure of the international System 
compels China and Russia to seek their strategic interests, increase their political influence and thereby become sole hegemonic power of the region, "states quickly understand that the best way to ensure their survival is to be the most powerful state in the system" (Mearsheimer \& Alterman, 2001). As many neorealists argue that the relative power relation between China and Russia cannot be simply neglected. Russia was once a superpower of the world and more like a "big brother" and strategic partner to China (Marsh, 2007).

While now, Russia has lost its dominance, and China is expected to be the next superpower of the world due to its exponential influence in the international arena. Similarly, China is not simply relying on its economic ties with Central Asia states but has intentions to seek superiority of the region rather than cooperating with Russia on shared interests. Therefore, to balance China's growing power in Central Asia, Russia is likely to compete to secure its leading position in dominating the region. Moscow will never agree to play a subordinate role to China at least in this region. Due to growing Chinses penetration into Central Asia, there will be changes in power distribution which will ultimately lead towards open rivalry between China and Russia. In short, the dynamics of Sino-Russian relations in central Asia fit closely the Neorealist Framework.

\section{Research methodology}

This research paper is a descriptive and explanatory study based on the missed method approach. It is a complete explanation of the causal mechanism of events leading to an extraordinary and definitive transition of relations between Russia and China from hostility to cooperation and coordination in an energy rich Central Asian region. This is a qualitative desktop-based study which relies on the method of documentary analysis of documentary sources. The study drew on both primary and secondary sources. In terms of primary documents, official statements and speeches of the presidents, prime ministers, and foreign ministers of both countries, as well as original government documents pertaining to the China and Russia's engagement in Central Asia. In addition to the selected online newspaper articles about the conflict. In terms of secondary sources, this study examined journal articles, published papers, books, and book chapters.

A mix of quantitative, primary, and secondary research methods were used to collect date for the study to describe, interpret, contextualize, and understand the topic of study. This study incorporated content analysis and thematic analysis methods to analyse the data. If offered an analysis after closely examining traditional and contemporary data, speeches of various leaders to identify main themes and patterns related to the study.

\section{Discussion and findings}

\subsection{Proximity of Central Asia with Russia and China}

The Central Asian region shares a greater proximity with both Russia and China. Russia has infrastructure connectivity wit Central Asia and share a common past under Soviet Union. Russia ruled this region for over 100 years, had shared cultures and language and always considered Central Asia as extension of its own territory. Russia shared a world largest bilateral border with Kazakhstan and out five three central Asian states host the Russian forces. Historically in Tsar regime Central Asia was not only economically but politically and military 
significant for Russia. Even the central Asia is not under Russia, but it is still crucial region for Russian security.

To China central Asia is crucial for the energy resources. China depends on Central Asian countries for gas, oil, and uranium from Turkmenistan and Kazakhstan, respectively. Central Asia is the trade destination of Chinese underdeveloped hinterlands and a Neighbour of Chinese Xinxiang and for the development of Xinxiang Central Asia is crucial for China. The economic rise of China challenged the Russian dominance in the central Asian region particularly after the completion of pipelines project. China dominates the larges and rising shares of energy companies of central Asia and some Russian companies as well. Since the year 2015 central Asia become the destination of huge Chinese investment and China shares a big part of this region. Many Chinese banks have given loans to the central Asian countries. Tajikistan and Kyrgyzstan are smaller states of central and ow a big part of their foreign debts to Chinese development banks which shows the growing dominance of China in the region that is surpassing the Russian influence.

\subsection{Russia's dominant position in Central Asia}

Russian in its foreign policy prioritizes its connections with important global actors, powerful military-political blocs and alliances, and influential international institutions. Neither of the first two are found in Central Asia. It has been in 2016 for the first time that Russia has started paying serious attention to Central Asia under the Vladimir Putin's leadership. As a result of Putin's more effective promotion of Russia as a major economic and political partner and a guarantor of regional stability, Russia has been able to strengthen its position in Central Asia, at least in part. However, given Russia's ongoing internal issues and shortcomings, the question of whether it can sustain this projection of strength remains yet to be seen. In any event, economic integration is difficult since the economies of Russia and Central Asia are more competitive than complimentary. Indeed, attracting external investment and securing markets in the global economy are economic imperatives for both Russia and Central Asia. The more economically educated Russian elites are beginning to recognise that diversifying Central Asian oil and gas export channels is both unavoidable and economically desirable (Dannreuther, 2001). The political sensitivity of a restored Russian participation for Central Asian governments must also be recognised. There are a few international organizations operating in Central Asia i.e., CSTO, EAEU and SCO.

The Collective Security Treaty Organization (CSTO) established in 2002, which includes Kazakhstan, Kyrgyzstan, and Tajikistan, is dominated by Russia. The CSTO, which serves as a vehicle for Moscow's residual military presence in Central Asia, may be less than the sum of its components. It is described as "one of the key elements of the current security framework in the post-Soviet space... and adjacent regions" in the Foreign Policy Concept, and "Russia seeks to facilitate the development of the CSTO into a prominent multifunctional international organisation" (Dubnov, 2018). It does not have any other big powers among its members, unlike the SCO. Eurasian Economic Union (EAEU), founded in 2014, is also active in Central Asia. It also involves a number of Central Asian countries, with Russia playing a key role. From the analysis of past and current relations, it is said that Russia has maintained "special relations" with Central Asian countries, pursuing both old and new ways of international cooperation. In order to maximize its influence in Central Asia, Russia needs to diversify its commitments and move beyond just power based military relations to greater economic and 
social commitments to engage in cooperative ventures with Central Asian states without indulging in competition.

\subsection{Does China have replaced Russia in the "New Great Game"?}

In the context of landmass and population, China and Russia are two of the largest states in the world and share a border of around 4133 kilometres, the sixth-longest international border (Statista, n.d.). Both states are significant economic hegemons with leading military capabilities in the world. They both are Veto powers in UN Security Council and also command sophisticated nuclear weapons. However, in the international system, the policies and positions of China and Russia are different. Today, four out of five major banks of the world are Chinese while Russia is trying to cope up with international sanctions and overall economic deficits. In international monetary system, the Chinese currency Renminbi has become its official currency while the Russian currency Ruble lacks such value. In terms of foreign policy, China has adopted a soft power approach while Russia still values the hard power approach in the international arena. China believes in its economic expansion while Russia uses the tool of territorial expansion (annexation) to influence the world.

After the disintegration of the Soviet, Russian Federation was not very much interested in investing in Central Asia rather more focused on its internal affairs and institutional build-up. So, Russia treated Central Asian states merely as a security buffer zone and benefited from the old pipeline links Russia inherited from the Soviet Union. However, when giant oil and gas reserves were discovered in Central Asia, Russia initiated a rapprochement with the states and increased its involvement in the political and economic affairs of the region (Paramonov \& Strokov, 2008). While the former Soviet republics started demanding more self-determination from Russia and diversified their relationship with the outer world. During this period, China expanded its area of influence in Central Asia and the Caspian region with huge investments in the trade and energy sector (Hynek, 2020). Chinses growing presence in Former Soviet Republics is not fully welcomed by Russian Federation, but China has already become a key actor and investor in the region. Furthermore, China will never back out of this region under Russia's pressure.

To China, Central Asia has become one of the most important regions of the world due to several reasons. To continue its economic growth, China has turned to Central Asia with ambitions to build trade infrastructure and diversify its energy resources in the region. For example, according to IMF, the annual trade between China and five Central Asian states in 2000 was 1.8 billion dollars and increased to almost 50 billion dollars in the year 2013. This increase in the trade sector shows China's significant role as a regional economic stabilizer. China stands as the most important trading partner in the world. As per, "the official statistics of each country in 2019, China is the largest trading partner to Kyrgyzstan and Uzbekistan by imports and is Turkmenistan's largest trading partner by exports. China also ranks high as a destination for the imports and exports of other Central Asian countries". (Goble, 2021) In this year 2021 a meeting of $\mathrm{C}+\mathrm{C} 5$ held that urged China and five central Asian republics to explore new avenues of cooperation for shared future.

Another important goal of China in Central Asia is related to the security of Xinjiang province. Establishing close ties will help China to overcome threats coming from the separatist movement in Uyghur Autonomous Region (Stratfor, 2013) Central Asia is like a trade outlet 
for Xiangjiang province to bring economic development and stability to this region. If this region is not secure, it could interrupt China's OBOR initiative.

Apart from these initiatives, the Five Soviets Republics are increasingly relying on Chinese technology both in the civilian and military sectors. Recently, Chinese-built drones have been bought by three Central Asian states. In 2019 many reports confirmed the presence of Chinese private security for the protection of China's assets including industrial sites and transportation networks across the region to protect BRI project (Goble, 2021). Not only this but the Chinese government is also accused of establishing military bases in Central Asian states, raising its military presence in the region (especially in Tajikistan). In short, the increasing economic, political and military growth of China in Central Asia is indicating that China is the potential actor to replace Russia in the New Great Game of this region.

\subsection{Russia and China's role in energy sector}

In the energy sector, Russia has had been the most influential actor in maintaining a monopoly over the oil and gas market in Central Asia for a longer period. The historical gas linkages and infrastructure established during the period of the USSR is the main reason for Russian gas companies' dominance as compared to Chinese and European companies (Hynek, 2020). The Central Asian gas pipeline that is connected to the Russian federation lies in northern Kazakhstan and is mainly controlled by Gazprom- a Russian majority state-owned energy corporation. LUKOIL, another big Russian company is actively present in the region with seven oil and gas onshore programs and three offshore programs in the Kazakhstan area of the Caspian shelf. Furthermore, about $90 \%$ of oil and $40 \%$ of natural gas are being produced by LUKOIL company in Kazakhstan. Moreover, Russia has been diversifying its gas industries by importing more gas from Uzbekistan and Turkmenistan and further increasing its gas production capacities in the region of Kyrgyzstan. In the region of Uzbekistan, both major Russian corporations, Gazprom and LUKOIL account for almost $20 \%$ of natural gas production. Russia's influence in the energy sector is aided by its deep-rooted understanding of the basic infrastructure of oil and gas transportation, thus plays a key role in the distribution of the natural resources of the region.

The Central Asian Hydrocarbons are a significant factor for Russia's modernizations of its energy sector and to fulfil the demand of its economic growth. In Tajikistan, the largest hydropower station project is Sangtuda HPS that was officially commissioned in July 2009. In this hydro-power station, the Russian federation with two of its major companies Rosatom and Inter RAO UES accounts for about $75 \%$ share (about US\$680 million investment) and the Tajikistan government accounts for $25 \%$ share ( $\$ 120$ million investment). In the context of natural resources extraction, Russia has been providing all these states with advanced technology, making the region dependent on Russian technology. However, central states mainly Turkmenistan and Kazakhstan having crucial stocks of hydrocarbons are enhancing their trade relations with external powers in the oil and gas sectors and reducing their reliance on Russian Federation.

Central Asia, a region rich in oil and natural gas reserves, has been a significant factor in China's energy strategy aimed to reduce its energy dependence on the Middle east. In the energy sector, China has some important goals in Central Asia that are: a) to expand its energy imports by increasing the share of oil and gas investment in Central Asia. b) to create a regional 
energy system by developing gas and oil infrastructure and secure its channels for more stable imports (energy security); and c) to increase Chinese control over strategic petroleum reserves and the overall production structure of the region.

Since 1992, trade between China and the Central Asian countries has grown from $\$ 527$ million to $\$ 40$ billion in 2011. In 2019, it touched 46.35 billion U.S. dollars, 1.2 times the trade volume in 2011. (Lingzhi, 2021). Currently, China has aimed to develop a regional free trade zone that will provide easier access to Central Asia's vast energy resources. China has sought to develop an 1800-kilometer Natural gas pipeline from Turkmenistan, the oil sector in Kazakhstan, and increased investment in infrastructure building in Tajikistan. All these major activities of China are being controlled by China National Offshore Oil Corporation (CNOOC), China National Petroleum Corporation (CNPC) and China Petroleum and Chemical Corporation (SINOPEC), and Petro China. All these major Chinese corporations have been working closely with the regional oil and gas companies to increase chine influence and outpace Russian presence in the regional energy sector.

It is important to mention that two significant oil and gas pipelines between China and Central Asia have been made operational during the last decade (Fazilov \& Chen, 2013). The first one is the Central Asia-China gas pipeline (with three pipelines completed in 2014) that starts from the border of Turkmenistan, Uzbekistan, and is running through central Kazakhstan, and crossing Xingjian Uyghur Autonomous Republic at the border town of Horgos. Through this pipeline, more than half of Turkmenistan's natural gas exports are being transported to China. Not only this, but a fourth pipeline of the same project is also underway that will be completed in the year 2022 .

The second one is the Kazakhstan-China oil pipeline that is a direct pipeline from Kazakhstan's Caspian shore to the Xingang region of China. This pipeline is controlled by China National Petroleum Corporation (CNPC) and the Kazakh oil company Kaz Munay Gas. In terms of infrastructure build-up, China's central project is the China-Kyrgyzstan-Uzbekistan railway, which will provide China easier access to the Persian Gulf and the Middle East through Iran and Turkmenistan, making Central Asia a pivotal factor in China's overall energy diplomacy. Such active Chinese strategy in Central Asia is weakening Russia's position in the region and China is becoming step by step more significant actor in the region's vast energy sector 7.5SCO AND Dynamics of Sino-Russian Relations.

For China and Russia, Multilateral organizations are one the most important tools to increase their sphere of influence and achieve their geopolitical and geoeconomics goals. After the Soviet Union disintegration, Russia needed to find new ways of regaining the lost influence and to promote its strategic interest in its immediate periphery. As a result, Moscow initiated many regional organizations to maintain close ties with Central Asian states and to restrain the entrance of other external actors. While for China, Constructive multilateral engagement is a significant tool of its soft power approach in the international system. Through these institutions, China has ensured its peaceful emergence and also protects its strategic interests along with its growing influence in the world.

The Shanghai Cooperation Organization, originally called as Shanghai Five mechanism, was initiated in the mid-1990s to develop political, economic, and security-based relations among China, Russia, and the Central Asian States. Along with this, resolving border demarcation 
issues and countering terrorism have had also been important regional targets of this organization. The two leading members of SCO have been using this platform as a vehicle to jointly cooperate on their shared interests in CA. Though SCO was born out of strengthened Sino-Russian relations, but this platform is not completely immune from hostility and collision of both states' interests. (Guang, 2007) This is because both states have different aspects regarding this organization, Russia wants Security cooperation (to get rid of terrorism, extremism) as the main agenda of this platform. However, the Chinese government is prioritizing an economic integration as the main focus of SCO, which is more attractive for the Central Asian states, the tendency is that China is becoming the "Big brother" within the SCO countries (Ali et al., 2019).

Russian policymakers have been aware of a growing Chinese presence in Central Asia via the SCO platform and the geopolitical balance is shifting in favour of Beijing. Therefore, to restore the balance of power in CA, Russia had invited India which has had close relations with the Russian Federation and is a geostrategic rival of China. Russia aimed that India as a member of SCO will tackle the leading role of China by binding it to the institutional obligations. Due to this reason, China initially opposed India's membership in SCO. While from the Central Asian states' perspective, the leading nations in SCO have been lacking cooperation to tackle common targets. Within this organization, every member state has been focusing to achieve its national interests, weakening the potential capabilities of this platform. Russia is only focusing to regain its status of Sole power in Central Asia, as well as that of a superpower in the international arena. While China is interested to ensure its security and energy needs through this platform. Most Central Asian governments perceive SCO as a tool of promoting and protecting of Russian and Chinese interests only, neglecting the objectives of Central Asian members of this organization. In this way both of the major powers China and Russia are making their ways and using SCO to promote their interests in Central Asia.

\section{Conclusion}

The analysis of the above research indicates that Russia's relation with Central Asian states has never been consistent, rather remained paradoxical. In the Post-Soviet period, Russia under Yeltsin's rule sought to maintain distance from CA and focused on its internal situations. During this time, Russia used to perceive this region as an economic burden and underestimated the strategic and geoeconomics significance of Central Asia. However, after Putin came into power, the Russian Federation behaviour towards CA changed dramatically. This was because Central Asia was becoming an attraction for other major external actors due to its rich energy resources. To regain its lost influence in the region, Putin adopted a pragmatic approach and a more coherent policy towards former Soviet Republics.

While weak Central Asian states had preferred to develop relations with global economic powers other than Russia. The rich energy and mineral resources discovered in these states resulted in fiercer competition between major powers and economic groupings of the world. In this competition, China has had emerged as the most significant actor with huge investment in trade and the energy sector. This gradual but significant rise of China is posing threat to Russia's strategic interests in the region and may lead towards rivalry between both states. Russia is more concerned with China's gradual penetration in this region due to fear of becoming a "junior partner" to China. Notwithstanding, Russia and China have pursued closer ties based on shared interests in the region through a significant multilateral organization. This 
is because China understands Russia's prominent influence over these states and without having stable relations with Russia, it would be difficult for the Chinese government to avail energy resources of this region.

Contrary to the popular belief, it is interesting to mention that China and Russia have managed to avoid open competition thus far. While there have been rare bouts of conflict, and the two countries have differing views on how to organise the regional order in Central Asia, these differences have not resulted into long-term open competition between Moscow and Beijing. In effect, the case of Sino-Russian ties defies common wisdom and fulfils realist theoretical predictions, as both countries were able to reconcile their interests. The Russian and Chinese decision makers are taking policy measures to prevent rivalry with each other. It is also an unintentional consequence of Moscow and Beijing's opposing Eurasia grand ambitions. Central Asia has shown to be manageable when viewed through the lens of their regional and global perspectives. China has gained a foothold in the Russian worldview, while Russia preserves its legacy in the Chinese vision.

China has offered immense economic opportunities and is engaged in various projects Central Asian states. However, it is interesting to mention that China is keeping an eye on the security interest of Russia. Russia is maintaining its presence in Central Asia through CSTO, EAEU and SCO and joint agreements on military cooperation. However, many analysts of International Relations have predicted that China may renounce its current policy of selfrestraint in Central Asia. This is because when China emerges as a superpower, it will not rely only on its economic participation but will encompass political and security realms to be called as the only hegemon of the region. In that situation, Chinese and Russian state-owned major corporations may openly compete not only on energy resources but also on strategic assets like distribution networks. China's promotion of its language and culture, presence of its security, and military exercises (in Tajikistan) in the Central Asian region further strengthen this analytical view of IR scholars.

Apparently, the shifting power of Central Asia between the two countries has not led to hostility or confrontation. Looking at the region on the subject of the Great Game leaves a very small agency in the Central Asian provinces for their future and facilitates the flexibility of SinoRussian relations in the region. Instead, it will be argued that despite regional differences and differing interests, Russia and China are not locked in a traditional conflict and do not compete for the same goals in Central Asia. The growing asymmetry between Russia and China in the region is accompanied by Moscow's acceptance of its fragile position, China's respect for Russia's strategic interests, and the shared responsibility for security and stability in the region. Apart from the Russian Chinese duopoly, the regions of Central Asia maintain a certain level of independent decision-making in line with their national interests. The economic future of Central Asia lies primarily in their homeland, and the strength of the Sino-Russian cooperation lies in the interests of the Central Asian Republics.

In order to sustain its influence in Central Asia, Russia will need to provide greater economic and social prospects to these countries in the long run. As a result, Russia's regional influence cannot be sustained just through power relations. Although Central Asian states are rich in natural resources, their regimes are still fragile and have been facing challenges of terrorism, extremism, and border issues. China and Russia should take joint initiatives through multilateral cooperation (e.g., SCO) to tackle these issues and ensure peace in the region. In 
the race of becoming the economic hegemons of the region, the energy resources and mineral wealth of Central Asian states should not be exploited. Rather China and Russia should work in cooperation to bring prosperity and economic development in the region. In short, despite the collision of strategic interests, China and Russia should seek stable co-existence in Central Asia to avoid destabilization of the region.

\section{Declaration of conflict of interest}

The author(s) declared no potential conflicts of interest(s) with respect to the research, authorship, and/or publication of this article.

\section{Funding}

The author(s) received no financial support for the research, authorship and/or publication of this article.

\section{References}

Ali, R., Ali, I., \& Ullah, S. (2019). SCO as a Passage to Regional Security: Future Developments and Opportunities for Pakistan. Liberal Arts and Social Sciences International Journal (LASSIJ), 3(1), 19-29. https://doi.org/10.47264/idea.lassij/3.1.3

Anishchuk, A. (2014, May 21). As Putin looks east, China and Russia sign \$400-billion gas deal. Reuters. $\quad$ http://www.reuters.com/article/2014/05/21/us-china-russiagasidUSBREA4K07K20140521

Aslam, T., \& Tariq, I. (2021). Pakistan's emerging regional politico-economic role in the SCO. Liberal Arts and Social Sciences International Journal (LASSIJ), 5(2), 159177. https://doi.org/10.47264/idea.lassij/5.2.11

Bailes, A. J., Dunay, P., Guang, P., \& Troitskiy, M. (2007). The Shanghai cooperation organization (Vol. 17). Stockholm International Peace Research Institute.

Bellacqua, J. (Ed.). (2010). The future of China-Russia relations. University press of Kentucky. http://www.jstor.org/stable/j.ctt2jcd70

Bolt, P. J. (2014). Sino-Russian relations in a changing world order. Strategic Studies Quarterly, 8(4), 47-69. http://www.jstor.org/stable/26270816

Bowen, W., \& Yang, L. (2016). Spotlight: "Shanghai Five": A paradigm mechanism for peace, development at border areas. http://www.scio.gov.cn/32618/Document/1474457/1474457.htm

Chase, M. S., Medeiros, E. S., Roy, J. S., Rumer, E. B., Sutter, R., \& Weitz, R. (2017). RussiaChina relations: Assessing common ground and strategic fault lines. The National Bureau of Asian Research.

Dannreuther, R. (2001). Can Russia sustain its dominance in Central Asia? Security Dialogue, 32(2), 245-258. https://doi.org/10.1177\%2F0967010601032002009

Dubnov, A. (2018). Reflecting on a quarter century of Russia's Relations with Central Asia (Vol. 19). Carnegie Endowment for International Peace, Washington.

Eder, T. S. (2013). China-Russia relations in Central Asia: Energy policy, Beijing's new assertiveness and $21^{\text {st }}$ Century geopolitics. Springer Science \& Business Media. 
Eurasia Asia Review News \& Analysis. (2017, May 6). Kazakhstan energy profile: Secondlargest oil reserves among former Soviet Republics - Analysis. EIA. http://www.eurasiareview.com/06052017-kazakhstan-energy-profile-secondlargest-oil-reserves-among-former-soviet-republics-analysis-2/

Fazilov, F., \& Chen, X. (2013). China and Central Asia: A significant new energy nexus. The European Financial Review, 4, 38-43. $\underline{\text { https://digitalrepository.trincoll.edu/cgi/viewcontent.cgi?article }=1085 \& \text { context }=\text { fac }}$ pub

Fettweis, C. J. (2000). Sir Halford Mackinder, geopolitics, and policymaking in the $21^{\text {st }}$ Century. The US Army War College Quarterly: Parameters, 30(2), 3. https://press.armywarcollege.edu/cgi/viewcontent.cgi?article=1974\&context=param eters

Goble, P. (2021). Beijing expanding size and role of its 'private' military companies in Central Asia. Eurasian Daily Monitor, 18(115). https://jamestown.org/program/beijingexpanding-size-and-role-of-its-private-military-companies-in-central-asia/>

Goldstein, L. J. (2020, February 20). "Russia's relation with China is growing despite setback". The National Interest. https://nationalinterest.org/feature/russias-relationship-chinagrowing-despite-setbacks-126111

Guang, P. (2007). Bishkek: SCO's Success in the Hinterland of Eurasia. China and Eurasia Forum Quarterly, 5(4), 3-6.

Hynek, O. (2020). Geopolitics of Central Asia: Between the Russian Bear and the Chinese Dragon. Central European Journal of Politics, 6(2), 73-93. https://pdfs.semanticscholar.org/2998/239a839ea01e3253123e606223065d7b496e.p $\underline{\mathrm{df}}$

Ismailova, E., \& Papava, V. (2010). The heartland theory and the present-day geopolitical structure of Central Eurasia. Institute of Strategic Studies of the Caucasus, 119. https://www.silkroadstudies.org/resources/pdf/Monographs/1006Rethinking-4.pdf

Koldunova, E. (2021). Sino-Russian border settlement and preventive diplomacy experience in Eurasia. In Case Studies on Preventive Diplomacy in the Asia-Pacific (pp. 33-41). https://doi.org/10.1142/9789811218576_0002

Lewis, J. W., \& Xue, L. (1993). Uncertain Partners: Stalin, Mao, and the Korean War (Vol. 4). Stanford University.

Lingzhi, Z. (2021). Analysis on the prospect of economic and trade cooperation between Central Asian countries and China. Economics and Innovative Technologies, 2021(2), 6. https://uzjournals.edu.uz/iqtisodiyot/vol2021/iss2/6/

Lukin, A. (1999). Russia's image of China and Russian-Chinese relations. East Asia, 17(1), 539. https://link.springer.com/article/10.1007/s12140-999-0002-3

Marsh, C. (2007). Russia Plays the China Card. The National Interest, (92), 68-73. https://www.jstor.org/stable/42896098

McFarlane, C. (2016). The importance of Central Asia. Transnational cooperation and international significance. GRIN Verlag.

Mearsheimer, J. J., \& Alterman, G. (2001). The tragedy of great power politics. WW Norton \& Company.

Melnikovová, L. (2020). China's interests in Central Asian economies. Human Affairs, 30(2), 239-252. $\underline{0022 / \mathrm{html}}$ https://www.degruyter.com/document/doi/10.1515/humaff-2020, A., \& Preljević, H. (2017). Sino-Russian relations in Central Asia since the end of the Cold War: Interaction, cooperation and challenges. Epiphany Journal of 
Transdisciplinary Studies, 10(1), 56-71. https://www.ceeol.com/search/article$\underline{\text { detail? } \mathrm{id}=664066}$

Paramonov, V., \& Strokov, A. (2008). Russian oil and gas projects and investments in Central Asia. Conflict Studies Research Centre, Defence Academy of the United Kingdom.

Peace Agreement Data Base. (2001, July 16). Treaty of good-neighborliness and friendly cooperation between the People's Republic of China and the Russian Federation. https://www.peaceagreements.org/view/1735/

Rumer, E. B. (2006). China, Russia and the Balance of Power in Central Asia. Institute for National Strategic Studies, National Defense University, Washington, DC.

Russian News Agency. (2021, March 22). Russia-China Friendship Treaty to be automatically extended for 5 years . Tass.com. https://tass.com/politics/1268537

Statista. (n.d.). Length of longest international land borders worldwide. https://www.statista.com/statistics/1103985/border-length-between-countries/

Stratfor. (2013, October 1). China's ambition in Xinjiang and Central Asia part 2. https://www.stratfor.com/analysis/chinas-ambitions-xinjiang-and-central-asia-part-2 